\title{
Kaldor Yaklaşımı Çerçevesinde İmalat Sanayii ve Hizmetler Sektörünün Ekonomik Büyüme Üzerindeki Etkisinin İncelenmesi: Seçili Geçiş Ekonomileri Örneği
}

\author{
Olcay Çolak ${ }^{1}$ (iD) Elchin Ismayilzada ${ }^{2}$ (iD \\ ${ }^{1}$ Dr. Öğr. Üyesi, Uşak Üniversitesi, İ̈BF, İktisat Bölümü, Uşak, Türkiye \\ olcay.colak@usak.edu.tr(Sorumlu Yazar/Corresponding Author) \\ ${ }^{2}$ Yüksek Lisans Öğrencisi, Uşak Üniversitesi, Lisansüstü Eğitim Enstitüsü, İktisat ABD, Uşak, Türkiye \\ talib.ismayil@mail.ru
}

\begin{tabular}{|c|c|}
\hline Mak: & ÖZ \\
\hline $\begin{array}{l}\text { Anahtar Kelimeler: } \\
\text { Kaldor'un Büyüme } \\
\text { Yasaları, İmalat Sanayii, } \\
\text { Hizmetler Sektörü, } \\
\text { Geçiş Ekonomileri. }\end{array}$ & $\begin{array}{l}\text { Ekonomik gelişmişliğin sağlanmasında sanayileşmenin rolü özellikle II. Dünya Savaşı sonrası } \\
\text { dönemde literatürde en çok tartışılan konulardan birisidir. Bu doğrultuda sermayenin kıt olduğu az } \\
\text { gelişmiş ve gelişmekte olan ülkelerde sanayileşme, ekonomik gelişmişliğin sağlanmasında kilit bir } \\
\text { role sahiptir. Ayrıca bu ülkeler açısından sermaye birikiminin yetersizliği de bir başka önemli } \\
\text { olgudur. Kaldor'un (1966) sanayileşmenin ekonomik büyümenin lokomotifi olduğu görüşünden yola } \\
\text { çıkarak bu çalışma sanayileşme ile verimliliğin üretim üzerindeki etkisini, hizmetler sektörünü de } \\
\text { içerecek şekilde, } 13 \text { seçili geçiş ekonomisi için uygulamalı olarak incelemeyi amaçlamıştır. Bu } \\
\text { bağlamda, yılllk panel veri seti kullanılarak, panel eşbütünleşme testleri ve panel eşbütünleşme } \\
\text { tahmincileri yardımıyla analiz gerçekleştirilmiştir. Kaldor'un (1966) ortaya koymuş olduğu farklı } \\
\text { modeller çerçevesinde, panel eşbütünleşme testleri sonuçları değişkenler arasında uzun dönemli } \\
\text { ilişkinin varlı̆ğna işaret etmiştir. Öte yandan, eşbütünleşme tahmincilerine göre sanayi sektöründeki } \\
\text { katma değerin hizmetler sektörüne kıyasla üretimi daha fazla arttırıcı etkiye sahip olduğu kanaatine } \\
\text { varılmıştır. Bununla birlikte sanayi sektöründeki verimliliğin, hizmetler ve diğer sektörlerdeki } \\
\text { verimliliğe kıyasla üretimi daha fazla arttırdığı da bir diğer önemli bulgu olarak dikkat çekmektedir. }\end{array}$ \\
\hline \multicolumn{2}{|c|}{$\begin{array}{c}\text { Investigation of the Impact of the Manufacturing Industry and Services Sector on } \\
\text { Economic Growth in the Framework of the Kaldor Approach: The Case of } \\
\text { Selected Transition Economies }\end{array}$} \\
\hline Article Info & 政 \\
\hline $\begin{array}{l}\text { Article History } \\
\text { Received: } 24.03 .2021 \\
\text { Accepted: } 27.04 .2021 \\
\text { Published: } 30.06 .2021 \\
\text { Keywords: } \\
\text { Kaldor's Growth Laws, } \\
\text { Manufacturing Industry, } \\
\text { Services Sector, } \\
\text { Transition Economies. }\end{array}$ & $\begin{array}{l}\text { The role of industrialization in ensuring the economic development is one of the most discussed } \\
\text { topics in the literature especially in the Post II. World War. In this direction, industrialization has a } \\
\text { key role in ensuring economic development for the less-developed and developing countries in where } \\
\text { capital is scarce. Furthermore deficiency in capital accumulation is another major fact for these } \\
\text { countries. Based on Kaldor's (1966) view that industrialization is the locomotive of economic } \\
\text { growth, this study aims to examine the effect of industrialization and productivity on production, by } \\
\text { including the services sector, for } 13 \text { selected transition economies. In this context, by using the annual } \\
\text { panel data set, the analysis was carried out by means of the panel cointegration tests and panel } \\
\text { cointegration estimators. Within the framework of different models introduced by Kaldor (1966), the } \\
\text { results of the panel cointegration tests indicate the existence of a long-run relationship between the } \\
\text { variables. On the other hand, according to the cointegration estimators, it is concluded that the value } \\
\text { added in the industry sector has a greater effect on increasing the production compared to the services } \\
\text { sector. Nonetheless, it draws attention as another important finding that productivity in the industrial } \\
\text { sector increases production more than the productivity in services and other sectors. }\end{array}$ \\
\hline
\end{tabular}

Atıf/Citation: Çolak, O. ve Ismayilzada, E. (2021). Kaldor Yaklaşımı Çerçevesinde İmalat Sanayii ve Hizmetler Sektörünün Ekonomik Büyüme Üzerindeki Etkisinin İncelenmesi: Seçili Geçiş Ekonomileri Örneği, Necmettin Erbakan Üniversitesi Siyasal Bilgiler Fakültesi Dergisi, 3(1), 82-100. 


\section{GİRIS}

Ekonomik büyüme, ekonomistlerin en çok tartıştıkları konulardan birisi olmakla beraber özelikle de gelişmekte olan ülkelerin (GOÜ) üzerinde çalıştığı ekonomik konuların başında gelmektedir. Ekonomik büyüme literatüründe en çok üzerinde durulan konulardan birisi olan ekonomik büyümenin sürdürülebilir olabilmesinin sanayi sektörüne bağl1 olduğu görüşüdür. Bu nedenle ülkelerin ekonomik kalkınması ile sanayileşme arasında doğru yönlü bir ilişki olduğu tezi dikkate alınması gereken bir gerçektir. Keza ülkelerde kalkınma planları hazırlanırken sanayileşme en önemli kısmı oluşturmaktadır. Bilindiği gibi sanayileşme yeni teknolojik gelişmeler, ekonomik, sosyal, kültürel değişkenler üzerinde etkisi vardır. Sanayileşmiş ülkelere baktığımızda aynı zamanda toplum refahının da yüksek olduğunu görmekteyiz. Dolaysıyla bu ülkelerde istihdamın yüksek olması, teknolojinin daha ulaşılabilir olması ve üretime entegrasyonu kişi başına düşen gelirin yüksek olması gibi birçok sebep kalkınmışlığında birer göstergesidir. Sanayi sektörü ile ekonomik büyüme arasındaki ilişki ilk kez Post-Keynesyen iktisatçılardan biri olan Kaldor tarafından incelenmiştir.

Kaldor (1966) çalışmasında bu ilişkiyi üç farklı yasa ile açıklamıştır. Birinci yasa aynı zamanda imalat sanayinin ekonomik büyümenin motoru olarak ifade edilmekte ve imalat sanayii üretim artışı ile büyüme arasında pozitif ilişkinin bulunduğunu belirtmektedir. İkinci yasa ise imalat sanayinde üretim artışı ve verimlilik artışı arasındaki pozitif yönlü ilişkinin varlığını ifade etmektedir. Bu yasa, aynı zamanda 1940'larda Doğu Avrupa ülkeleri için bu tür bir ilişkiyi keşfeden Hollandalı iktisatçı P.J. Verdoorn'un adıyla Verdoorn yasası olarak da anılmaktadır. Üçüncü yasa, imalat sanayindeki çıktı büyümesi ile imalat sanayi dışındaki sektörlerin verimlilik artışı arasında pozitif ilişkinin bulunduğunu belirtmektedir (Kaynak, 2011: 153).

Tarım ve hizmetler sektöründeki yenilikler de imalat sektöründeki firmaların yaptığı yenilikler nedeniyle gelişmektedir. Günümüzde teknolojik değişimin ekonomiler üzerindeki olumlu etkileri herkes tarafından kabul edilmektedir. Birçok çalışmada, teknolojik değişimin refah düzeyini sağlayan en önemli etkenlerden birisi olduğu görüşüdür. Teknolojideki yaşanan yenilikler tarım ve hizmetler sektöründe yaygın bir biçimde kullanılmakla birlikte asıl en önemli kullanım alanı sanayi sektörüdür. $\mathrm{Bu}$ nedenle günümüzde hızlı sanayileşmenin, ülkelerin yüksek bir ekonomik büyüme hızına ulaşabileceğine dair yaygın bir görüş hâkimdir (Arısoy, 2008: 6).

Bu çalışma, Kaldor'un imalat sanayinin verimlilik ve ekonomik büyüme üzerindeki etkisini hizmetler sektörünü içerecek şekilde üç farklı yasası bağlamında 13 seçili geçiş ekonomisinde 19902018 dönemi için dinamik panel veri analiziyle incelemeyi amaçlamaktadır. Çalışmanın geri kalan kısmı aşağıdaki gibi düzenlenmiştir: İkinci bölümde ilgili literatür özetlenecektir. Üçüncü bölümde, ampirik analizde kullanılan veriler ve yönteme değinilecektir. Dördüncü bölümde ampirik sonuçları gösterilecektir. Çalışmanın sonucunun yer aldığı beşinci kısmında ise genel bir değerlendirme ve elde edilen bulgular doğrultusunda birtakım politika önerilerine yer verilecektir.

\section{Literatür Taraması}

Post Keynesyen ekonominin gelişiminde önemli bir figür olan Kaldor (1966) İngiltere'deki zayıf büyüme performansının nedenleri üzerine bir konuşma gerçekleştirmiştir. Konuşmanın bir parçası olarak Kaldor, imalat sanayi sektörünün ekonomik büyümenin ana motoru olduğunu savunan üç yasa öne sürdü. Daha sonra, ekonomik büyüme çalışmalarının ivme kazanmasıyla birlikte, Kaldor'un bu görüşünden yola çıkarak bir dizi iktisatçı tarafından imalat sanayiinin ekonomik büyüme üzerindeki etkisini açıklamak için yapılan uygulamalı çalışmalarda gerek seçilen örneklem ve zaman periyodu gerekse seçilen yöntemin farklılı̆̆ından dolayı kesin bir uzlaşının sağlandığını ifade etmek güçtür. Bu çerçevede Stoneman (1979), yılında yaptığı çalışmada 1800-1979 dönemlerinde İngiltere ekonomisi için 
Kaldor yasalarını (SEKK) yöntemi ile analiz yapmıştır. Çalışmanın sonuçları, Kaldor yasalarını destekleyen sonuçlara ulaşılmadığını göstermiş̧tir. Ateşoğlu (1993) yaptığı çalışmada 1965-1988 yılları arası dönemde (EKK) yöntemi kullanarak ABD ekonomisi için Kaldor yasalarını analiz etmiştir. Analiz sonucunda, Kaldor yasalarını destekleyici bulgulara ulaşılmıştır.

Gelişmiş ülkelere yönelik son zamanlarda panel veriye dayalı çalışmalar da yaygın hale gelmiş ve çalışmaların Kaldor'un büyüme yasalarını ayrı ayrı ele alarak farklı sonuçlara ulaştığı görülmüştür. Bu doğrultuda, Çetin (2009) 1981 ve 2007 yılına ait verileri kullanarak Türkiye ve AB ülkeleri için Kaldor'un birinci yasasını, Granger nedensellik testi ve (OLS) yöntemi ile analiz etmiştir. Bulgular, Türkiye ve araştırmaya katılmış diğer ülkelerde sanayi sektörü ile ekonomik büyüme arasında pozitif bir ilişki olduğunu göstermektedir. Ener ve Arıca (2011) ise Kaldor'un ilk yasasının 1980-2008 döneminde gelir düzeyi yüksek ekonomilere sahip 23 OECD ülkesi için geçerli olup olmadığını panel veri analizi yardımıyla incelenmiştir. Ampirik analizden elde edilen bulgular Kaldor'un birinci yasasının, ilgili dönem aralığında seçilmiş ülkelerin ekonomik büyümesiyle uyumlu olduğunu göstermektedir. Romero ve McCombie (2016) ise Genelleştirilmiş Momentler Yöntemi tekniği (GMM) yardımıyla 1976 ve 2006 dönemine ilişkin verilerle 12 imalat sanayi örneği ile yüksek gelirli 11 OECD ülkesi için Kaldor-Verdoorn yasasını analiz etmişlerdir. Çalışmanın bulguları, imalat sanayide ölçeğe göre artan getiri hipotezini önemli ölçüde destekleyen güçlü kanıtlar sağladığını ve ayrıca yüksek teknolojili imalat sanayilerinin, düşük teknolojili imalat sanayilerinden daha büyük ölçek getirisi sergilediğini görülmüştür. Çalışmada bunlara ek olarak yüksek teknoloji endüstrilerinde gözlemlenen ölçeğe göre getirilerin büyüklüğündeki artışların etkisiyle, son on yılda imalatta ölçeğe göre getirilerin büyüklüğünün arttığını da ortaya koymuştur. Marconi vd. (2016), dinamik panel veri analizini kullanarak, 1990-2011 yılları arasında Türkiye de dahil olmak üzere 63 orta ve yüksek gelirli ülkeden oluşan bir örneklem için Kaldor'un birinci ve ikinci yasalarını analiz etmiştir. Analiz sonucu, Kaldor'un birinci ve ikinci yasalarını desteklemekte ve imalat sektörünün büyümesi, özellikle orta gelirli ülkelerde, ekonomik kalkınma ve verimlilik artışları için önem arz etmektedir. Çalışma ayrıca, imalat ihracatının kalkınma süreciyle ilişkili olduğunu ve orta gelirli ülkelerdeki döviz kurunun bu sürece katkıda bulunduğunu doğrulamaktadır.

Gelişmiş ülkelerle olan gelişmişlik farkını kapatmada sanayileşmenin büyük bir öneme sahip olduğu ve ileri düzeyde sanayileşmeyi başarabilen Asya ülkelerine yönelik uygulamalı çalışmaların da literatürde önemli yere sahip olduğu görülmektedir. Bu çerçevede Mamgain (1999) sanayileşme açısından büyük atılım gerçekleştirmiş Güney Kore, Singapur, Malezya, Endonezya ve Tayland gibi ülkeler için 1960-1988 yılına ilişkin veriler yardımıyla Kaldor'un yasalarını (EKK) ve (FGLS) yöntemi kullanarak analiz etmiştir. Elde edilen sonuçlar ülkelere göre değişiklik göstermektedir. Kaldor'un ilk yasası tüm ülkeler için geçerliyken, ikinci yasa Güney Kore ve Malezya için geçerlidir. Kaldor'un üçüncü yasası ise sadece Güney Kore için geçerlidir. Benzer şekilde Mercan vd. (2015) 1965-2012 dönemini kapsayacak bir şekilde yıllık verilerle yeni sanayileşen ülkeler için Kaldor yasasının geçerliliğini yeni nesil panel eş bütünleşme yöntemi kullanarak test etmiş̧ler. Ampirik bulgular, söz konusu ülkeler için imalat sanayi üretimindeki artışların ekonomik büyümeyi $\% 4,5$ oranında arttırdığını işaret etmiştir. Elde edilen bu bulgular doğrultusunda, Kaldor'un birinci yasasının bu ülkelerde geçerli olması söz konusu olmuştur.

Sanayileşmenin ekonomik kalkınmanın sağlanmasında önemli görüldüğü az gelişmiş ve gelişmekte olan ülkelere yönelik çalışmaların da yaygın hale geldiği söylenebilir. Yukarıda değinildiği üzere, bu tür ülkelere yönelik gerçekleştirilen uygulamalı çalışmalarda da elde edilen bulguların gerek yöntem gerekse seçilen örneklem ve zaman periyoduna bağlı olarak farklılaşması söz konusudur. Bu bağlamda son 20 yılda hızlı sanayileşme ve ekonomik büyüme performansı kaydeden Çin ekonomisine yönelik Hansen ve Zhang (1996) Çin'in 28 bölgesi için 1985 ile 1991 yıllarını kapsayacak şekilde 
Kaldor yasalarını sıradan en küçük kareler yöntemiyle (SEKK) sınamış ve Kaldor'un her üç yasasının Çin ekonomisinde geçerliliğini tespit etmiştir. Wang ve Li (2010) birim-kök, eş-bütünleşme ve Granger nedensellik testi yardımıyla 1990 ve 2008 dönemine ilişkin verileri kullanarak Çin'de GSYH ile hizmetler sektörü arasındaki ilişkiyi araştırmışlardır. İlgili dönem aralığında yapılan çalışmada, uzun dönemde ekonomik büyüme ile hizmetler sektörü arasında anlamlı bir ilişki olduğu saptanmıştır.

Yukarıda bahsedilen ülke ve ülke grupları haricinde münferit olarak ülke bazlı diğer uygulamalı çalışmalar da literatürde mevcuttur. Yapılan bu çalışmaların hizmetler sektörünün ekonomik gelişmişlik üzerindeki etkisini incelemeye yönelik olması da dikkat çekicidir. Bu doğrultuda Tandrayen-Ragoobur (2010) küçük bir ada ülkesi olan Mauritius'da, kısa ve uzun dönemde hizmetler sektörünün ekonomik büyüme üzerindeki etkisini 1975 ve 2009 yılına ilişkin verileri kullanarak test etmiştir. Çalışmada, hizmetler sektöründeki farklı faaliyetlerin ekonomik büyüme üzerindeki etkisini elde etmek için sınır test yaklaşımı kullanılmıştır. Araştırma sonucunda, hizmet sektörünün GSYH'ye olumlu katkıda bulunduğunu ve bunun yanı sıra uzun dönemde hizmet sektöründen kişi başı GSYH'ye doğru nedensellik ilişkisi var iken, kısa dönemde ise kişi başı GSYH'den hizmetlere doğru bir nedensellik ilişkisi gözlemlenmiştir. Rahman vd. (2011)'de yapmış oldukları analizde, 1972'den 2008'e kadar olan zaman serisi verilerini kullanarak, Bangladeş için GSYH ile tarım, sanayi ve hizmetler çıktısı arasındaki nedensellik ilişkisini incelemişlerdir. Çalışmada değişkenler arasındaki ilişki Granger Nedensellik / Blok Dışsallık Wald testi kullanarak analiz edilmiştir. Test sonuçları, GSYH ile tarım ve sanayi sektörü arasında iki yönlü nedensellik ilişkisi bulunmuştur. Ampirik çalışma aynı zamanda sanayi sektöründen tarım sektörüne ve GSYH'den hizmet sektörüne tek yönlü nedensellik bulmuştur. Alhowaish (2014), 1969-2012 döneminde Suudi Arabistan için hizmet sektörünün ekonomik büyümedeki rolünü zaman serisi teknikleri ile incelemiştir. Ampirik sonuçlar hizmet sektörü ve ekonomik büyüme arasında uzun dönemli istikrarlı dinamik bir denge ilişkisi olduğunu göstermektedir. Buna göre, Suudi Arabistan’da hizmet sektöründeki her \%1'lik artış, ekonomik büyümeye \%0.93 katkıda bulunuyor.

Sanayileşmenin ekonomik gelişmişlik için önemli görüldüğü ve bu doğrultuda farklı dönemlerde rekabetçiliği ön plana çıkaracak şekilde çeşitli teşvik ve politikalarla desteklendiği Türkiye ekonomisine yönelik literatürde uygulamalı çalışmaların son zamanlarda artış gösterdiği görülmektedir. Bu kapsamda Güçlü (2013) tarafından yapılan çalışmada Türkiye'de imalat sanayii ile ekonomik büyüme ilişkisi 1990-2000 verileri temel alınarak test edilmiştir. Çalışmada, (SEKK) regresyon analizinin yanı sıra mekânsal (spatial) panel veri yöntemi analize dahil edilmiştir. Yapılan çalışmada imalat sanayi üretiminin uzun vadede bölgesel kalkınmayı olumlu yönde etkilediğini tespit etmiştir. Arısoy (2013) ise 1963-2005 dönemini kapsayacak şekilde Türkiye ekonomisi için eş bütünleşme ve nedensellik testlerini kullanarak Kaldor yasalarının geçerliliğini analiz etmiştir. Çalışmanın bulgularına göre Türkiye ekonomisinde sanayi sektörünün itici bir rol oynadığını söyleyen Kaldor yasasının aksine ekonomik büyümenin sanayi sektörü üretimini artıracağı sonucuna ulaşılmıştır.

Öte yandan hizmetler sektörünün ekonomik gelişmişlik üzerindeki etkisini inceleyen çalışmalar da Türkiye ekonomisi bağlamında incelenmiştir. Bu doğrultuda İnamoğlu (2013) 1968-2006 dönemine ilişkin temel alındığı çalışmada, Türkiye'de hizmet sektörünün gelişimi ve ekonomik büyümeye etkisini vektör otoregresyon (VAR) ve nedensellik testleri yardımıyla incelemiştir. Test sonuçlarına göre, tarım ve hizmet sektörleri ekonomik büyümeye etki etmekte ve ekonomik büyümeden de etkilenmektedir. Ancak sanayi sektörünün bu etkiye sahip olmadı̆̆ 1 sonucuna varılmıştır. Yetiz ve Özden (2017) EngleGranger nedensellik testleri ile etki-tepki ve varyans ayrıştırma analizleri yardımıyla 1960-2015 dönemini kapsayacak şekilde Türkiye ekonomisi için GSYH ile tarım, sanayi ve hizmetler sektörleri arasında nedensellik ilişkisi incelenmiştir. Araştırma sonuçları bu değişkenler arasında uzun dönemli bir ilişki olduğunu göstermektedir. Çalışmada, tarım sektöründen GSYH, sanayi ve hizmetler sektörüne 
doğru tek yönlü nedensellik ilişkisi bulunmuş, ancak tarım sektörünün diğer sektörlerden etkilenmediği görülmüştür. Uğurlu ve Tuncer (2017) birlikte yapmış olduğu çalışmada 1995 ve 2011 yılına ilişkin verilerle Türkiye'de ekonomisi için sanayi ve hizmet sektörlerinin büyüme ve istihdama katkılarını girdi-çıktı yöntemiyle analiz etmiştir. Çalışma bulguları, Türkiye ekonomisindeki başlıca sektörlerin sanayi sektöründen oluştuğunu hizmetler sektörünün ise büyüme üzerinde sınırlı katkılara sahip olduğunu göstermektedir. Bununla birlikte, bazı hizmet sektörlerinin Türkiye ekonomisinde üretim, istihdam, verimlilik üzerinde önemli katkılarda bulunduğu görülmüştür.

\section{MODEL, VERİ SETİ ve YÖNTEM}

\section{Model ve Veri Setine İliş̧kin Açıklamalar}

Kaldor Kanunu çerçevesinde, sanayi sektörü katma değeri ve istihdamı ile ekonomik gelişmişlik arasındaki ilişki, 1990-2018 dönemi için Doğu Bloğu ve Sovyet Sosyalist Cumhuriyetler Birliği (SSCB) bünyesinden ayrılan ve geçiş ekonomileri olarak adlandırılan ülkeler için irdelenecektir ${ }^{1}$. Bu bağlamda Kaldor Kanunu'nun üç temel modelinin genişletilmiş çerçevede incelenmesinin söz konusu olduğu bu çalışmada, Kaldor'un büyümenin motoru olarak kabul ettiği sanayi sektörünün ekonomik gelişmişlik üzerindeki etkisi ile hizmetler sektörünün de dahil edilmesiyle kurulan modeller panel veri analizi çerçevesinde doğrusal kalıpta aşağıdaki gibidir:

$$
\begin{aligned}
\text { Model I(a) } & G D P_{i t}=\alpha_{0}+\beta_{1} I V A_{i t}+\varepsilon_{i t} \\
\text { Model I(b) } & G D P_{i t}=\alpha_{0}+\beta_{2} S V A_{i t}+\varepsilon_{i t} \\
\text { Model I(c) } & G D P_{i t}=\alpha_{0}+\beta_{3} I V A_{i t}+\beta_{4} S V A_{i t}+\varepsilon_{i t}
\end{aligned}
$$

Denklemlerde bağımlı değişken olarak kişi başı gayri safi yurtiçi hasıla $\left(\mathrm{GDP}_{\text {it }}\right)$ yer alırken, IVA $_{\text {it }}$ sanayi sektörü katma değerini, $\mathrm{SVA}_{i t}$ ise hizmetler sektörü katma değerini göstermektedir. Öte yandan sanayi sektörünün verimlilik üzerine etkisi, Verdoorn Yasası olarak bilinmekte ve hizmetler sektörünü de içerecek şekilde genişletilmiş olarak aşağıdaki denklemler vasıtasıyla incelenecektir.

$$
\begin{aligned}
& \text { Model II(a) } \quad E I_{i t}=\alpha_{0}+\beta_{5} I V A_{i t}+\varepsilon_{i t} \\
& \text { Model II(b) } \quad E S_{i t}=\alpha_{0}+\beta_{6} S V A_{i t}+\varepsilon_{i t}
\end{aligned}
$$

Buna göre 4 ve 5 nolu denklemlerde bağımlı değişkenler sırasıyla sanayi sektörü ve hizmetler sektörü istihdam oranını vermektedir. Öte yandan sanayi sektöründeki işgücü verimliliğin, üretim üzerindeki etkisi yine hizmetler sektörünü de dikkate alacak şekilde aşă̆ıdaki modeller vasıtasıyla incelenmesi söz konusu olacaktır.

$$
\begin{array}{cl}
\text { Model III(a) } & G D P_{i t}=\alpha_{0}+\beta_{7} E I_{i t}+\varepsilon_{i t} \\
\text { Model III(b) } & G D P_{i t}=\alpha_{0}+\beta_{8} E S_{i t}+\varepsilon_{i t} \\
\text { Model III(c) } & G D P_{i t}=\alpha_{0}+\beta_{9} E I_{i t}+\beta_{10} E S_{i t}+\varepsilon_{i t}
\end{array}
$$

Yukarıda kurulan modeller çerçevesinde çalışmada kullanılan değişkenlere ilişkin veriler Dünya Bankası'nın World Development Indicators (WDI) adlı veri tabanından 1990-2018 dönemini kapsayacak şekilde derlenmiştir. Bununla birlikte, ampirik analizde kullanılan değişkenler, doğal logaritmik dönüşüme tabi tutulmuştur. Çalışmada kullanılan değişkenlere ilişkin tanımlayıcı istatistiklere Tablo 1'de yer verilmiştir.

1 Örneklem bünyesinde yer alan ülkeler sırasıyla şu şekildedir: Arnavutluk, Azerbaycan, Belarus, Gürcistan, Kazakistan, Kırgizistan, Kuzey Makedonya, Moldova, Özbekistan, Rusya, Sırbistan, Tacikistan ve Ukrayna. 
Tablo 1. Tanımlayıcı İstatistikler

\begin{tabular}{lrrrrr}
\hline Değişkenler & Gözlem Sayısı & Ortalama & Standart Sapma & Minimum & Maksimum \\
\hline LGDP & 377 & 7.891 & 0.820 & 5.905 & 9.369 \\
LIVA & 377 & 22.618 & 1.794 & 17.720 & 27.097 \\
LSVA & 377 & 23.130 & 1.704 & 19.009 & 27.548 \\
LEI & 377 & 3.015 & 0.375 & 2.106 & 3.713 \\
LES & 377 & 3.791 & 0.220 & 3.126 & 4.209 \\
\hline
\end{tabular}

\section{YÖNTEM}

Sanayi sektörü ve hizmetler sektörü katma değerinin, kişi başı çıktı büyümesi, verimlilik artışı ve söz konusu sektörlerdeki verimlilik düzeylerinin kişi başı çıtı üzerindeki etkisinin dinamik panel veri analizi çerçevesinde incelenmesinde, panel eşbütünleşme testleri ve eşbütünleşme tahmincilerinden yararlanılacaktır. Yamak (2000), Diaz-Bautista (2003) ve Arısoy (2013), literatürde yer alan uygulamalı çalışmalarının birçoğunun basit regresyon analizi çerçevesinde Kaldor'un modellerinin sınandığını fakat bu tarzdan analizlerin iki nedenden dolayı sakıncalı olduğunu vurgulamışlardır. Birinci neden, basit regresyon analizinin tahmin edilen modellerde yer alan ilgili değişkenler arasında anlamlı ilişkinin varlığına dayanmakta ve uzun dönem ilişki üzerinde bir çıkarım yapmaya olanak tanımamaktadır. İkinci neden, analizlerde kullanılan sanayi üretimi ve büyüme gibi değişkenlerin diğer pek çok makro iktisadi değişkende olduğu gibi trend içermeleri ve durağan olmamaları söz konusudur. Dolayısıyla sahte regresyon başta olmak üzere diğer bazı sorunların ortaya çıkması, bu etkilerin göz ardı edilmesiyle ortaya çıkabilecek ve tahminlere ilişkin tutarsız çıkarımlar yapılmasına sebebiyet verebilecektir. $\mathrm{Bu}$ doğrultuda, eşbütünleşme analizi aynı derecede bütünleşik serilerle gerçekleştirilebilmekte ve değişkenler arasında uzun dönem dinamiklerinin varlığını tespit etmekte önemli bir yöntem olarak kabul edilmektedir.

Öte yandan dinamik panel veri analizi çerçevesinde öncelikle kullanılan panel veri setinin yapısını incelemek önem arz etmektedir. Bu çerçevede, değişkenler arasında homojenlik ve yatay kesit bağımlılı̆̆1 gibi özelliklerinin incelenmesi gerekmektedir. Havuzlanmış EKK tahmincisinden elde edilen eğim tahminlerinin dağılımına bağlı eğim homojenliği yaklaşımını esas alarak Pesaran ve Yamagata (2008) normal dağılıma uygun olarak delta testi $(\tilde{\Delta})$ ile ortalama ve varyans sapmas1 düzeltilmiş, normal dağılımlı hatalara sahip düzeltilmiş delta $\left(\tilde{\Delta}_{\text {adj. }}\right)$ istatistiklerini aşağıdaki gibi elde etmişlerdir:

$$
\tilde{\Delta}=\sqrt{N}\left(\frac{N^{-1} \tilde{S}-k}{\sqrt{2 k}}\right) \quad \text { ve } \quad \tilde{\Delta} \operatorname{adj} .=\sqrt{N}\left(\frac{N^{-1} \tilde{S}-E\left(\tilde{z}_{i T}\right)}{\sqrt{\operatorname{Var}\left(\tilde{z}_{i T}\right)}}\right)
$$

Denklemde yer alan $\tilde{S}$ istatistiği, Swamy (1970) tarafından geliştirilen, her bir eğim katsayısına uyarlanabilen test istatistiğidir. Öte yandan kesit birimlerinin, serilerin herhangi birinde meydana gelen değişim veya şoktan etkilenip etkilenmedikleri, yatay kesit bağımlılığ testleri ile incelenebilmektedir. $\mathrm{Bu}$ çalışmada, Pesaran (2004) tarafindan geliştirilen $C D$ ve $\mathrm{CD}_{\mathrm{LM}}$ testleri ile yatay kesit bağımlılığının durumu incelenecektir. Pesaran'a (2004) göre Breusch ve Pagan (1980) tarafindan geliştirilen LM testi, kesit birimlerinin (N) sayısı sonsuza yaklaştıkça etkin sonuçlar üretememekte ve $\mathrm{N}$ ile zaman boyutunun (T) büyük olduğu durumlar için Pesaran (2004) LM testinin şu versiyonunu geliştirmiştir: 


$$
C D=\sqrt{\frac{2 T}{N(N-1)}\left(\sum_{i=1}^{N-1} \sum_{j=i+1}^{N} \hat{\rho}_{i j}\right) \rightarrow N(0,1)}
$$

Seriler arasında uzun dönemli ilişkinin varlı̆̆ının tespitinde yararlanılacak olan panel eşbütünleşme analizine geçmeden önce serilerin birim kök içerip içermediğine bakılmalıdır. Özellikle zaman serileri ile yapılan analizlerde birim kökün varlığında gerçekleştirilecek tahminlerde ortaya sahte regresyon sorunu çıkabilmektedir. Bir başka ifade ile geleneksel t, F testleri ve $\mathrm{R}^{2}$ değerleri sapmalı sonuçlar verebilmektedir. $\mathrm{Bu}$ durum panel veri analizinde de karşılaşılan önemli bir sorundur. Literatürde, panel veri ile gerçekleştirilen birim kök testleri birinci nesil ve ikinci nesil testler olarak nitelendirilmektedir. Birinci nesil testler, birimler arasında korelasyon olmadığını yani yatay kesit bağımlılı̆̆ının olmadığını varsaymaktadır. Korelasyon varsa bu testlerin gücü zayıftır. İkinci nesil panel birim kök testlerinin temel özelliği ise birimlere ait seriler arasında korelasyon olduğunu varsaymasıdır (Tatoğlu, 2012: 199). Bu bağlamda, öncelikle yatay kesit bağımlılığı ile heterojenliği dikkate almayan Hadri (2000) durağanlık testi sınamasına yer verilmiştir. Zaman serilerindeki KPSS testinin panel veriye uyarlanmış hali olan ve Lagrange Çarpanı (LM) testine dayanan bu sınamada, panel verinin dengeli olması zorunluluğu vardır. Ayrıca, hata terimlerinin normal dağıldığının varsayıldığı bu testte, zaman boyutu (T) ile kesit boyutunun $(\mathrm{N})$ sonsuza gittiği durumda da asimptotik olarak geçerlidir (Tatoğlu, 2012: 210). Hadri (2000) tarafindan geliştirilen bu testte, birinci nesil birim kök testlerinden farklı olarak sıfır hipotezinin durağanlığı dikkate alması söz konusudur. Bu çerçevede, öncelikle her bir kesit birim için KPSS testi uygulanmakta, ardından da $\mathrm{Z}$ istatistiği aşağıdaki gibi hesaplanmaktadır.

$$
Z=\frac{\sqrt{N}\left[\overline{L M}-\mu_{\overline{L M}}\right]}{\sigma_{\overline{L M}}} \sim N(0,1)
$$

Öte yandan incelenen seriler arasında yatay kesit bağımlılı̆̆1 ve heterojenlik gibi durumların varlığı, birinci nesil birim kök testlerinin asimptotik özelliklerini etkilemesinden dolayı, literatürde yatay kesit bağımlılığını ve heterojenlik yapısını dikkate alacak şekilde ikinci nesil birim kök testleri geliştirilmiştir. Pesaran (2007) tarafından geliştirilen ve yatay kesit genelleştirilmiş Dickey-Fuller (CADF) adını alan birim kök testinde, yatay kesit bağımlılı̆̆1, gecikmeli yatay kesit ortalamalarına dayalı ADF regresyonunun birinci fark1 alınarak yok edilmektedir (Tatoğlu, 2012: 223). Birim kökün olmadığını vurgulayan sıfır hipotezi, alternatifine karşı test edilmekte ve kesit biriminin uzunluğunun zaman boyutundan fazla olması durumunda da uygulanabilen CADF test istatistiği, hem panel için hem de paneli oluşturan tüm kesit birimleri için hesaplanabilmektedir (Akbaş, vd. 2013: 797). Bu çerçevede Pesaran (2007), her bir kesit birimi için aşağıdaki CADF testini şu şekilde hesaplamıştır:

$$
C A D F_{i}=\frac{\Delta y_{i}^{\prime} M_{w i} y_{i,-1}}{\sqrt{\hat{\sigma}_{\epsilon, i}^{2}\left(y_{i,-1}^{\prime} M_{w i} y_{i,-1}\right)}}
$$

İncelenen serilerin birinci farkında durağan olması halinde, yani I (1) sürecini takip etmesi durumunda, bu serilerin doğrusal bileşimlerinin de uzun dönemde eşbütünleşik olacağına işarettir. $\mathrm{Bu}$ çalışmada Westerlund (2007) ile Westerlund ve Edgerton (2007) tarafından geliştirilen eşbütünleşme testlerine yer verilecektir. Her iki testin de en önemli özelliği, seriler arasında korelasyonu ve heterojenlik durumunu dikkate almaları ve bu koşullar altında etkin sonuçlar üretmeleridir. Bu doğrultuda Westerlund (2007) hata düzeltme mekanizmasına dayalı olarak aşağıdaki veri yaratma sürecini takip edecek şekilde bir model geliştirmiştir: 


$$
\Delta y_{i t}=\delta_{i}^{\prime} Z_{t}+\alpha_{i} y_{i t-1}+\beta_{i}^{\prime} x_{i t-1}+\sum_{j=1}^{p i} \alpha_{i j} \Delta y_{i t-j}+\sum_{j=0}^{p i} \gamma_{i j} \Delta y_{i t-j}+e_{i t}
$$

$\mathrm{Z}_{\mathrm{t}}$ modelin deterministik unsurlarını içerirken, $\delta_{i}^{\prime}$ deterministik unsurlarla ilişkin olarak parametre vektörlerini göstermektedir (Westerlund, 2007: 715). Bu çerçevede Westerlund (2007) eşbütünleşmenin olmadığını vurgulayan sıfır hipotezini test etmek için ikisi grup ikisi de panel çerçevesinde dört adet istatistik geliştirmiştir. Grup istatistikleri elde edilirken 13 nolu denklemin her bir kesit birimi (i) için tahmin edilmesi ve ardından $\alpha_{i}$ 'nin parametrik yaklaşımla tahmin edilmesi neticesinde grup istatistikleri aşağıdaki gibi hesaplanmaktadır:

$$
g_{\tau}=N^{-1} \sum_{i=1}^{N} \frac{\widehat{\alpha}_{i}}{\operatorname{se}\left(\widehat{\alpha}_{i}\right)} \text { ve } g_{\alpha}=N^{-1} \sum_{i=1}^{N} \frac{T \widehat{\alpha}_{i}}{\widehat{\alpha}_{i}(1)}
$$

14 nolu bu denklemde gösterilen grup istatistikleri, heterojenliğin varlığı altında, her bir kesit birimi için hata düzeltme modelinin tahmin edilmesiyle hesaplanmıştır. Panel verinin homojenliği durumunda ise 13 nolu denklemle birlikte bağımlı değişken için düzey durumunun geçerli olduğu denklemin birlikte tahmin edilmesi sonucunda hesaplanan kalıntılarla ortak hata düzeltme teriminin elde edilmesiyle aşağıdaki panel istatistiklerinin hesaplanması da olanaklı hale gelmiştir:

$$
p_{\tau}=\frac{\widehat{\alpha}}{s e(\widehat{\alpha})} \text { ve } p_{\alpha}=T \hat{\alpha}
$$

Sonuçların sağlamlılığı ve karşılaştırma yapabilmek adına, yatay kesit bağımlılı̆̆ 1 ve heterojenliğ dikkate alacak şekilde Westerlund ve Edgerton (2007) tarafından geliştirilen panel LM eşbütünleşme testi vasıtasıyla seriler arasında uzun dönemli ilişkinin incelenmesi söz konusu olacaktır. Bu çerçevede Westerlund ve Edgerton (2007) aşağıda belirtilen bir veri yaratma sürecinden yola çıkarak test istatistiğini geliştirmişlerdir:

$$
y_{i t}=\alpha_{i}+x_{i t}^{\prime} \beta_{i}+z_{i t}
$$

16 nolu denklemde $\mathrm{i}=1,2, \ldots, \mathrm{N}$ ve $\mathrm{t}=1,2, \ldots, \mathrm{T}$ olmak üzere sırasıly kesit ve zaman birimlerini göstermek üzere, $\mathrm{x}_{\mathrm{it}}$ tam rassal yürüyüş sürece sahip $k \times 1$ boyutunda açıklayıcı değişkenler vektörünü içermekte ve $z_{i t}$ hata terimi olup şu şekilde ayrışmaktadır:

$$
z_{i t}=u_{i t}+v_{i t} \text { ve } v_{i t}=\sum_{j=1}^{t} \eta_{i j}
$$

$\eta_{i t}$ sıfır ortalama ve sabit varyansa sahip olmak üzere, bağımsız ve özdeş dağılımlı (i. i. d) bir sürece sahiptir. Bu bilgiler ışığında, McCoskey ve Cao'dan (1998) yola çıkarak, Westerlund ve Edgerton (2007), LM test istatistiğini aşağıdaki denklem vasıtasıyla elde etmişlerdir (Westerlund ve Edgerton, 2007: 186).

$$
L M_{N}^{+}=\frac{1}{N T^{2}} \sum_{i=1}^{N} \sum_{t=1}^{T} \widehat{\omega}_{i}^{-2} S_{i t}^{2}
$$

$S_{\text {it, }} Z_{\text {it }}$ 'nin tam değiştirilmiş tahmininin kısmi toplam süreci olup, $\widehat{\omega}_{i}^{2}, 7$ nolu denklemde yer alan $\mathrm{u}_{\mathrm{it}}$ 'nin koşullu uzun dönem varyans değerine eşittir. Yatay kesit bağımlılığı altında, "eşbütünleşme

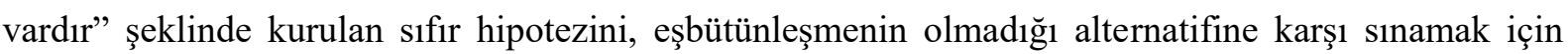
geliştirilen LM test istatistiğinin yatay kesit bağımlılığını dikkate alabilmesi için bootstrap dağılımına uygun olasılık değerleri geliştirilmiştir. Hesaplanan LM test istatistiğinin, bootstrap kritik değerlerinden düşük çıkması durumunda eşbütünleşmenin olduğunu vurgulayan sıfır hipotezi kabul edilecektir. 
Eşbütünleşme ilişkisi tespit edildikten sonra, uzun dönemli ilişkinin büyüklüğü ve yönünün tespit edilmesinde eşbütünleşme parametre tahmincilerinden faydalanılmaktadır. Bu çerçevede Pesaran (2006) tarafından geliştirilen ortak ilişkili etkiler tahmincisi (CCE) ile Eberhard ve Bond (2009) tarafından geliştirilen ilerletilmiş ortalama grup tahmincisi (AMG) yöntemlerinden yararlanılmıştır. Her iki yöntemin de en önemli avantajı yatay kesit bağımlılığı ve heterojenliği göz önünde bulundurmalarıdır. Pesaran (2006) tarafından geliştirilen CCE tahmincisi, örneklem boyutunun küçük olduğu durumda da etkin sonuçlar üretmektedir (Pesaran, 2006: 967). Ayrıca, bu yöntem her bir kesit birimi için tahmin sonuçlarını elde etmeyi olanaklı hale getirmektedir. Bununla birlikte, CCE tahmincisi yatay kesit bağımlılığı ve heterojenlik altında, gözlemlenemeyen ortak faktörler ile açıklayıcı değişkenlerin dışsallığı altında ve farklı seviyelerde durağanlığında da uzun dönemli katsayıların üretilmesini sağlamaktadır (Erataş, vd. 2013: 29). Bu çerçevede ortak ilişkili etkiler ortalama tahmincisi (common correlated effects mean group estimator, CCEMG) ile ortak ilişkili etkiler havuzlanmış tahmincisi (common correlated effects pooled estimator, CCEP) tahmincileri 19 nolu denklemdeki gibi elde edilmektedir (Pesaran, 2006: 982-986).

$$
\hat{b}_{C C E M G}=N^{-1} \sum_{i=1}^{N} \hat{b}_{i} \text { ve } \hat{b}_{C C E P}=\left(\sum_{i=1}^{N} \theta_{i} x_{i} M_{w} x_{i}\right)^{-1} \sum_{i=1}^{N} \theta_{i} x_{i} M_{w} x_{i}
$$

Eberhard ve Bond'un (2009) geliştirdiği AMG tahmincisi, iki aşamalı olup, birimlere özgü sabit etkiler ve birimlere özgü faktör yükleriyle modellenebilen ortak faktörlerin modele dahil edilmesiyle birimler arası korelasyonu dikkate almakta ve CCE tahmincisi gibi küçük örneklem durumunda da etkin sonuçlar üretebilmektedir. Eberhard ve Bond (2009) iki aşamalı olarak AMG tahmincisini aşağıdaki denklemlerle elde etmişlerdir:

$$
\begin{aligned}
& \text { AMG (i) } \Delta y_{i t}=b^{\prime} \Delta x_{i t}+\sum_{t=2}^{T} c_{t} D_{t}+e_{i t} \Rightarrow \widehat{c_{t}} \equiv \widehat{\mu_{t}} \\
& \mathrm{AMG} \text { (ii) } y_{i t}=\alpha_{i}+b_{i}^{\prime} x_{i t}+c_{i} t+d_{i} \widehat{\mu_{t}}+e_{i t} \\
& \widehat{b_{A M G}}=N^{-1} \sum_{i=1}^{N} \widehat{b}_{\imath}
\end{aligned}
$$

20 nolu denklem AMG tahmincisi için birinci aşamayı göstermekte ve T-1 kadar zaman kuklası $\left(\widehat{\mu_{t}}\right)$ eklenerek elde edilen standart birinci farkı alınmış havuzlanmış regresyonu ifade etmektedir. 21 nolu denklem ise ikinci aşamayı gösterirken, zaman kuklası her bir kesit birimine ilişkin regresyonlara dahil olurken, doğrusal trend terimi ( $\mathrm{t}$ ) de bu aşamada denkleme dahil edilmiştir. Son olarak, 22 nolu denklem birinci ve ikinci aşamanın tahminiyle elde edilen AMG tahmincisini vermektedir.

\section{BULGULAR ve TARTIŞMA}

Dinamik panel veri analizi çerçevesinde, daha detaylı analize geçilmeden önce çalışmada kullanılan panel veri setinin özelliklerinin incelenmesi önem arz etmektedir. Bu bağlamda, değişkenlerin yatay kesit bağımlılığı ve homojenlik gibi özelliklere sahip olup olmadığına bakılmalıdır. Tablo 2'nin üst kısmı Pesaran ve Yamagata (2008) tarafından geliştirilen delta $(\widetilde{\Delta})$ ve düzeltilmiş delta $\left(\tilde{\Delta}_{\text {adj }}\right)$ testlerinin sonuçlarını göstermektedir. Buna göre her bir model için yapılan tahmin sonuçlarına göre homojenliğin olduğunu vurgulayan sıfır hipotezi hem delta $(\tilde{\Delta})$ hem de düzeltilmiş delta $\left(\tilde{\Delta}_{\text {adj }}\right)$ testleri çerçevesinde $\% 1$ anlamlılık düzeyinde reddedilmiş ve değişkenlere ilişkin eğim parametrelerinin heterojen olduğu kanısına varılmıştır. Tablo 2'nin alt kısmı Pesaran (2004) tarafından geliştirilen CD $_{\mathrm{LM}}$ ve $C D$ yatay kesit bağımlılığı testlerine ayrılmıştır. Yatay kesit bağımsızlığının olduğunu vurgulayan sıfır hipotezinin her bir model için hem $\mathrm{CD}_{\mathrm{LM}}$ hem de $\mathrm{CD}$ testleri bağlamında $\% 1$ anlamlılık düzeyinde reddedilmesi söz konusu olmuştur. 
Değişkenlerin birim köke sahip olup olmadığının incelenmesi detaylı analizlerin gerçekleştirilmesi açısından önem arz etmektedir. Serilerin birim köke sahip olması durumunda gerçekleştirilecek analizler sahte regresyon gibi sorunlara yol açabilecek ve sonuçların sapmalı ve tutarsız olarak gerçekleşmesine yol açacaktır. Ayrıca, değişkenler arasında yatay kesit bağımlılığı ve heterojenliğin varlığı, durağanlık ve birim kök sınamaları için yine önemli bir husus olarak göz önünde bulundurulması gerekmektedir. Bu doğrultuda öncelikle Hadri (2000) tarafından geliştirilen ve LM testi olarak da bilinen durağanlık testi uygulanmıştır ve sonuçlara Tablo 3'te yer verilmiştir. İlgili serinin durağan olduğuna yönelik sıfır hipotezi, değişkenlerin düzey durumları itibariyle tüm değişkenler için reddedilirken, serilerin birinci farkı alınması neticesinden hesaplanan LM test istatistiği kritik değerlerden düşük çıkmış ve durağanlığın olduğunu vurgulayan sıfır hipotezi serilerin birinci farkının alındığı durum için reddedilememiştir. Öte yandan seriler arasında yatay kesit bağımlılığı ve heterojenliğin varlığının tespit edilmesi, birim kök sınamasında bu hususların da dikkate alınmasını gerektirmektedir. Buna göre yatay kesit bağımlılı̆̆ ile heterojenliği dikkate alan CADF testi uygulanmıştır. İlgili serinin birim kök içerdiğini vurgulayan sıfır hipotezi serilerin durağan olduğu durum için reddedilemezken, birinci farkın alındığı durum için hesaplanan $Z_{\bar{t}}$ istatistiği LSVA serisi için \% 5, LIVA serisi için \% 10 ve diğer seriler için \% 1 anlamlılık düzeylerinde reddedilmiştir. Gerek Hadri (2000) LM durağanlık testi gerekse Pesaran (2007) tarafından geliştirilen CADF istatistiği için serilerin birinci farkının alınması neticesinde durağanlaştı̆̆ kanaatine varılmıştır.

Tablo 2. Homojenlik ve Yatay Kesit Bă̆ımlılı̆̆ Testleri

\begin{tabular}{|c|c|c|c|c|c|c|c|c|}
\hline \multicolumn{9}{|c|}{ A-Homojenlik Testleri } \\
\hline Test & (1a) & (1b) & $(1 \mathrm{c})$ & $(2 a)$ & $(2 b)$ & $(3 a)$ & $(3 b)$ & $(3 c)$ \\
\hline$\tilde{\Delta}$ & $\begin{array}{c}20.60 * \\
(0.000)\end{array}$ & $\begin{array}{c}29.97^{*} \\
(0.000)\end{array}$ & $\begin{array}{c}22.26^{*} \\
(0.000)\end{array}$ & $\begin{array}{c}28.07^{*} \\
(0.000)\end{array}$ & $\begin{array}{l}28.18^{*} \\
(0.000)\end{array}$ & $\begin{array}{c}32.00^{*} \\
(0.000)\end{array}$ & $\begin{array}{c}23.55^{*} \\
(0.000)\end{array}$ & $\begin{array}{l}26.36^{*} \\
(0.000)\end{array}$ \\
\hline$\tilde{\Delta}_{\text {adj }}$ & $\begin{array}{l}21.38^{*} \\
(0.000)\end{array}$ & $\begin{array}{c}31.10 * \\
(0.000)\end{array}$ & $\begin{array}{c}23.14^{*} \\
(0.000)\end{array}$ & $\begin{array}{l}29.13^{*} \\
(0.000)\end{array}$ & $\begin{array}{c}29.24 * \\
(0.000)\end{array}$ & $\begin{array}{c}33.21 * \\
(0.000)\end{array}$ & $\begin{array}{l}24.44 * \\
(0.000)\end{array}$ & $\begin{array}{l}27.39 * \\
(0.000)\end{array}$ \\
\hline Test & \multicolumn{7}{|c|}{ B-Yatay Kesit Bağımlılığı Testleri } & (3c) \\
\hline $\mathrm{CD}_{\mathrm{LM}}$ & $\begin{array}{c}81.86^{*} \\
(0.000) \\
32.62 * \\
(0.000)\end{array}$ & $\begin{array}{c}79.83^{*} \\
(0.000) \\
32.23^{*} \\
(0.000)\end{array}$ & $\begin{array}{c}77.68 * \\
(0.000) \\
31.87 * \\
(0.000)\end{array}$ & $\begin{array}{l}87.16^{*} \\
(0.000) \\
33.56^{*} \\
(0.000)\end{array}$ & $\begin{array}{c}47.30 * \\
(0.000) \\
24.82 * \\
(0.000)\end{array}$ & $\begin{array}{c}82.30 * \\
(0.000) \\
32.69 * \\
(0.000)\end{array}$ & $\begin{array}{c}61.53 * \\
(0.000) \\
28.32 * \\
(0.000)\end{array}$ & $\begin{array}{l}69.45^{*} \\
(0.000) \\
30.05^{*} \\
(0.000)\end{array}$ \\
\hline
\end{tabular}

Not: * \% 1 anlaml1l1k düzeyini göstermektedir.

Tablo 3. Panel Durağanlık ve Birim Kök Testleri

\begin{tabular}{lccc}
\hline Değişkenler & Hadri-LM Testi & CADF Testi $\left(\boldsymbol{Z}_{\overline{\boldsymbol{t}}}\right.$ istatistiği) & Sonuç \\
\hline LGDP & 1.433 & 1.454 & $\mathrm{I}(1)$ \\
$\Delta$ LGDP & $0.415^{\star}$ & $-3.672^{*}$ & \\
LIVA & 1.316 & -1.204 & $\mathrm{I}(1)$ \\
$\Delta$ LIVA & $0.346^{\star}$ & $-1.484^{* * *}$ & \\
LSVA & 3.444 & 0.984 & $\mathrm{I}(1)$ \\
$\Delta$ LSVA & $0.388^{\star}$ & $-2.090^{* *}$ & \\
EI & 2.163 & 0.618 & $\mathrm{I}(1)$ \\
$\Delta$ EI & $-3.091^{\star}$ & $-3.312^{*}$ & \\
ES & 2.786 & -0.056 & $\mathrm{I}(1)$ \\
$\Delta$ ES & $-3.160^{\star}$ & $-4.109^{*}$ &
\end{tabular}

Not: $*, * *, * *$ surasıyla $\% 1, \% 5$ ve $\% 10$ anlamlllık düzeylerini göstermektedir. ${ }^{\wedge} \% 1$ anlamlılık düzeyinde sıfir hipotezinin kabul edildiğini göstermektedir. 
Serilerin birinci farkında durağan olması, serilerin doğrusal kombinasyonlarının da uzun dönemde ilişkiye sahip olabileceğini yani eşbütünleşik olabileceğini göstermektedir. Değişkenler arasında uzun dönemli ilişkinin incelenmesi maksadıyla yatay kesit bağımlılı̆̆ 1 ve heterojenliği dikkate alan ve Westerlund (2007) tarafından hata düzeltme mekanizmasına dayalı eşbütünleşme testi ile Westerlund ve Edgerton (2007) tarafindan geliştirilen LM eşbütünleşme testleri uygulanmış ve tahmin sonuçlarına Tablo 4'te yer verilmiştir. Tablo 4'ün üst kısmı, Westerlund (2007) tarafından geliştirilen hata düzeltme mekanizmasına dayalı eşbütünleşme testi tahmin sonuçlarını yansıtmaktadır. Panel ve grup için dört farklı test istatistiğinin elde edildiği bu yaklaşımda, heterojenliğin varlığı nedeniyle grup istatistiklerinin $\left(\mathrm{g}_{\tau}, \mathrm{g}_{\alpha}\right)$ dikkate alınmas1 gerekmektedir. Buna göre hesaplanan grup istatistiklerinin farklı anlamlılık düzeylerinde kritik değerlerden düşük çıkması neticesinde, eşbütünleşmenin olmadığını vurgulayan sıfır hipotezi tüm modeller için reddedilmiş ve eşbütünleşme ilişkisinin varlığı tespit edilmiştir. Elde edilen bu bulgunun sağlamlı̆̆ 1 açısından Westerlund ve Edgerton (2007) tarafından geliştirilen panel LM eşbütünleşme testi de uygulanmış ve sonuçlar Tablo 4'ün alt kısmında verilmiştir. Eşbütünleşmenin olduğunu vurgulayan sıfır hipotezi, her bir model için hesaplanan LM test istatistiğinin bootstrap kritik değerlerinden küçük çıkması neticesinde kabul edilmiş ve eşbütünleşme ilişkisinin olduğu kanaatine varılmıştır.

Tablo 4. Panel Eşbütünleşme Testleri

\section{A-ECM Eşbütünleşme Testi}

\begin{tabular}{|c|c|c|c|c|c|c|c|c|}
\hline Test & (1a) & (1b) & (1c) & $(2 a)$ & $(2 b)$ & (3a) & (3b) & Eşbütünleşme \\
\hline \multirow[t]{2}{*}{$\mathrm{g}_{\tau}$} & $-6.754 *$ & $-5.603 * * *$ & $-6.154 * *$ & $-7.497 *$ & $-9.287 *$ & $-7.467 *$ & $-8.034 *-6.954 * *$ & \multirow[t]{2}{*}{ Var } \\
\hline & $(0.007)$ & $(0.086)$ & $(0.013)$ & $(0.000)$ & $(0.000)$ & $(0.001)$ & $(0.000) \quad(0.030)$ & \\
\hline \multirow[t]{2}{*}{$\mathrm{g}_{\alpha}$} & $-5.047 * *$ & $-4.486 * * *$ & $-4.204 * *$ & $-4.548 * * *$ & * $-7.349 *$ & $-5.252 * *$ & $*-8.172 *-4.425 * * *$ & \multirow[t]{2}{*}{ Var } \\
\hline & $(0.044)$ & $(0.066)$ & $(0.073)$ & $(0.052)$ & $(0.001)$ & $(0.021)$ & $(0.000) \quad(0.092)$ & \\
\hline \multirow[t]{2}{*}{$\mathrm{p}_{\tau}$} & $-7.224 *$ & $-6.139 * *$ & $-6.693 *$ & $-7.391 *$ & $-9.695 *$ & $-8.207 *$ & $-8.519 *-7.560 *$ & \multirow[t]{2}{*}{ Var } \\
\hline & $(0.005)$ & $(0.022)$ & $(0.005)$ & $(0.001)$ & $(0.000)$ & $(0.001)$ & $(0.000) \quad(0.006)$ & \\
\hline \multirow[t]{2}{*}{$\mathrm{p}_{\alpha}$} & $-7.212 *$ & $-6.534 * *$ & $-6.409 * *$ & $-6.829 * *$ & $-10.020 *$ & $-7.730 *$ & $-12.440 *-6.578 * *$ & \multirow[t]{2}{*}{ Var } \\
\hline & $(0.013)$ & $(0.019)$ & $(0.023)$ & $(0.014)$ & $(0.000)$ & $(0.003)$ & $(0.000) \quad(0.031)$ & \\
\hline
\end{tabular}

\section{B-LM Eşbütünleşme Testi}

\begin{tabular}{llllllllll} 
Test & $(1 \mathrm{a})$ & $(1 \mathrm{~b})$ & $(1 \mathrm{c})$ & $(2 \mathrm{a})$ & $(2 \mathrm{~b})$ & $(3 \mathrm{a})$ & $(3 \mathrm{~b})$ & $(3 \mathrm{c})$ & Eşbütünleşme \\
\hline LM İst. & 0.436 & -0.082 & 2.077 & 1.012 & -0.043 & 0.452 & 0.535 & 1.858 & Var \\
& $(0.442)$ & $(0.588)$ & $(0.754)$ & $(0.230)$ & $(0.333)$ & $(0.512)$ & $(0.468)$ & $(0.597)$ & \\
\hline
\end{tabular}

Not: $*, * *, * * *$ sirasıly $\% 1, \% 5$ ve $\% 10$ anlamlılık düzeylerini göstermektedir.

Uzun dönemli eşbütünleşme ilişkisinin yönü ve büyüklüğünün de tahmin edilmesi, incelenen modellerin diğer çalışmalarla ne ölçüde uygunluk gösterdiği ve ne açıdan farklılıklarının olduğunun tespit edilmesi açısından önem arz etmektedir. Bu doğrultuda panel eşbütünleşme tahmincileri olarak kabul edilen ve Pesaran (2006) tarafından geliştirilen ortak ilişkili etkiler tahmincisi (CCE) ile Eberhard ve Bond (2009) tarafından geliştirilen ilerletilmiş ortalama grup tahmincisi (AMG) yöntemlerinden yararlanılmış ve tahmin sonuçları Tablo 5'te gösterilmiştir.

Gerek CCE tahmincisi gerekse AMG tahmincisiyle elde edilen bulgular, sanayi sektörü katma değerinin kişi başı reel GSYİH üzerinde uzun dönemde pozitif etkisinin olduğunu doğrulamaktadır. Buna göre her iki tahminci için sanayi sektörü katma değerinde \% 1'lik artış, kişi başı GSYİH'yi sırasıyla uzun dönemde $\% 0.77$ ve $\% 0.76$ oranında arttırmaktadır. 
Tablo 5. Panel Eşbütünleşme Tahmincileri

\begin{tabular}{|c|c|c|c|c|c|c|c|c|}
\hline \multicolumn{9}{|c|}{ A-CCE Tahmincisi } \\
\hline Değișkenler & (1a) & (1b) & (1c) & $(2 a)$ & (2b) & (3a) & $(3 b)$ & (3c) \\
\hline LIVA & $\begin{array}{r}0.777^{*} \\
(0.099)\end{array}$ & & $\begin{array}{c}0.438^{*} \\
(0.080)\end{array}$ & $\begin{array}{c}0.239^{*} \\
(0.049)\end{array}$ & & & & \\
\hline LSVA & & $\begin{array}{c}0.747^{*} \\
(0.089)\end{array}$ & $\begin{array}{c}0.363^{*} \\
(0.087)\end{array}$ & & $\begin{array}{c}0.135^{* *} \\
(0.063)\end{array}$ & & & \\
\hline EI & & & & & & $\begin{array}{c}0.086^{* *} \\
(0.037)\end{array}$ & & $\begin{array}{r}0.131 * \\
(0.031)\end{array}$ \\
\hline ES & & & & & & & $\begin{array}{c}0.063^{*} \\
(0.013)\end{array}$ & $\begin{array}{r}0.050^{*} \\
(0.011)\end{array}$ \\
\hline Gözlem sayısı & 377 & 377 & 377 & 377 & 377 & 377 & 377 & 377 \\
\hline RMSE & 0.107 & 0.115 & 0.065 & 0.051 & 0.081 & 0.209 & 0.215 & 0.122 \\
\hline$\chi^{2}$ istatistiği & $61.15^{*}$ & $69.19^{*}$ & $89.24^{*}$ & $23.51^{*}$ & $4.56^{* *}$ & $5.33^{* *}$ & $21.01^{*}$ & $27.01^{*}$ \\
\hline \multicolumn{9}{|c|}{ B-AMG Tahmincisi } \\
\hline LIVA & $\begin{array}{c}0.768^{*} \\
(0.096)\end{array}$ & & $\begin{array}{r}0.431 * \\
(0.076)\end{array}$ & $\begin{array}{r}0.239^{*} \\
(0.049)\end{array}$ & & & & \\
\hline LSVA & & $\begin{array}{c}0.739 * \\
(0.094)\end{array}$ & $\begin{array}{l}0.363^{*} \\
(0.092)\end{array}$ & & $\begin{array}{c}0.135^{* *} \\
(0.063)\end{array}$ & & & \\
\hline EI & & & & & & $\begin{array}{c}0.084^{* *} \\
(0.037)\end{array}$ & & $\begin{array}{c}0.130^{*} \\
(0.030)\end{array}$ \\
\hline ES & & & & & & & $\begin{array}{c}0.063^{*} \\
(0.013)\end{array}$ & $\begin{array}{r}0.051^{*} \\
(0.013)\end{array}$ \\
\hline Gözlem sayısı & 377 & 377 & 377 & 377 & 377 & 377 & 377 & 377 \\
\hline RMSE & 0.109 & 0.130 & 0.071 & 0.051 & 0.082 & 0.214 & 0.220 & 0.136 \\
\hline$\chi^{2}$ istatistiği & $62.87^{*}$ & $60.81^{*}$ & $90.31 *$ & $24.03 *$ & $4.53^{* *}$ & $5.19 * *$ & $22.78^{*}$ & $24.71^{*}$ \\
\hline
\end{tabular}

Not: ${ }^{*}, * *, * * *$ sirasıyla $\% 1$ ve $\% 5$ anlamlılık düzeylerini göstermektedir.

Ayrıca, Kaldor'un hipotezinin hizmetler sektörünü de içerecek şekilde tahmin edilen modellerde (Model 1c) sanayi sektörü katma değerinde meydana gelen \% 1'lik artışın her iki tahminciye göre sırasıyla kişi başı GSYİH’yi \% 0.438 ve \% 0.431 oranında arttırması söz konusu olmuştur. Bununla birlikte hizmetler sektörünün kişi başı GSYİH'yi arttırıcı etkisinin sanayi sektörüne kıyasla göreceli olarak daha düşük kalmış ve her iki model için kişi başı GSYİH'yi \% 0.363 oranında arttırmıştır. Öte yandan hizmetler sektörünün ayrı olarak ele alındığı durumda (Model 1b) kişi başı GSYİH'yi \% 0.74 ve $\% 0.73$ oranında arttırıcı etki yaratmıştır. Elde edilen bu bulgular doğrultusunda, uzun dönemde Kaldor'un sanayi sektörünün büyümenin motoru olduğunu savunduğu görüş, örneklem kapsamında yer alan geçiş ekonomileri açısından doğrulanmaktadır. Sanayi sektörünün, hizmetler sektörüne kıyasla kişi başı GSYİH'yi göreceli olarak daha fazla arttırıcı etkiye sahip olması, bir dizi faktörle açıklanabilir (Szirmai, 2009; Attiah, 2019). Öncelikle, sanayi kesiminde sermayenin getirisinin, diğer sektörlere kıyasla daha yüksek olmasından dolayı, sanayi sektörü bu ülkelerde sermaye birikimi için birtakım özel firsatlar sunmakta ve bu da sanayi kesiminin büyüme üzerinde daha fazla etkiye sahip olmasına yol açmaktadır. Ayrıca, Kaldor (1966) ile Fagerberg ve Verspagen (1999) tarafindan vurgulandığ 1 üzere, sanayi sektöründe diğer sektörlere kıyasla ölçek ekonomilerinin daha yaygın görülmesinden dolayı, daha fazla firsatlar yaratması da söz konusudur. Bir başka gerekçe de sanayi sektörünün alt kollarında geriye ve ileriye doğru doğrudan bağlantı, diğer sektörlere kıyasla daha fazla olabilir. Bu da sanayi sektörü ve özelinde imalat sanayiinde pozitif dışsallıklar yaratarak yatırımların artmasına sebebiyet verebilir (Attiah, 2019: 115). 
Verdoorn kanunu olarak da bilinen sanayi sektörünün verimlilik üzerine etkisinin pozitif ve anlamlı olarak gerçekleştiği görülmektedir. Buna göre sanayi sektörü katma değerinde meydana gelen \% 1'lik bir artışın sanayi sektöründeki istihdamı her iki tahmin yönteminde de \% 0.239 oranında arttırması söz konusu olmuştur. Hizmetler sektörünün dahil edilmesiyle gerçekleştirilen tahminlerde, hizmetler sektörü katma değerindeki artış uzun dönemde istihdamı her iki modelde de \% 0.135 oranında arttırmaktadır. Elde edilen bu bulgular, sanayi sektörü bünyesinde daha nitelikli üretim faktörlerinin istihdamı ve göreceli olarak daha ileri teknolojiyi bünyesinde barındırmasından dolayı, verimlilik arttırma potansiyelinin uzun dönemde hizmetler ve diğer sektörlere kıyasla fazla olduğunu göstermektedir. Ayrıca, Romero ve McCombie'nin (2016) de bulgularına uygun olarak, her iki sektörde de ölçeğe göre artan getirilerin varlığı geçerli olmakla birlikte, sanayi sektöründe göreceli olarak daha yaygın olduğu söylenebilir.

Sanayi sektöründeki verimlilik artışlarının üretim üzerine etkisi, hizmetler sektörünü de dahil edecek şekilde uzun dönem için tahmin edilmiştir. Buna göre sanayi sektöründeki verimlilik artış1, hizmetler sektörüne kıyasla üretimi daha fazla arttırıcı etkiye sahip olmaktadır. Bu bağlamda, sanayi sektöründe \% 1'lik verimlilik artışının üretimi her iki tahminci çerçevesinde sırasıyla \% 0.086 ve \% 0.084 civarında arttırması söz konusudur. Öte yandan hizmetler sektöründe verimlilikte meydana gelen artış üretimi her iki tahminciye göre \% 0.063 oranında artıımıştır. Son olarak, sektörlerdeki verimlilik artışlarının bir arada ele alındığı durumda ise sanayi sektöründeki verimlilik artışının hizmetler sektörüne kıyasla çıktıyı daha fazla arttırıcı etkiye sahip olduğu görülmektedir. Her iki tahminciden elde edilen sonuçlara göre sanayi sektöründeki verimlilik artışı üretimi \% 0.13 civarında arttırırken, hizmetler sektöründeki verimlilik artışının üretimi \% 0.05 civarında arttırdığı görülmektedir. Elde edilen bu bulgu, sanayi sektöründe ölçeğe göre artan getirilerin varlığının, sanayi sektöründe işgücü verimliliğinde artışa ve neticede üretimi olumlu yönde etkilediği bağlamında Kaldor'un (1966) üçüncü yasasını kısmen doğrular niteliktedir. Zira sanayi sektörü dışında kalan hizmetler ve diğer sektörlerde azalan verimlerin kısmen işlemesi nedeniyle diğer sektörlerden sanayi sektörüne doğru işgücünün transferinin kısmen gerçekleşmesi söz konusu olabilir. Bu durum, uzun dönemde Kaldor'un (1966) öngörülerinden kısmi sapmalar yaratarak, anılan ülkelerde bir bütün olarak sanayi sektöründeki verimlilik ve üretim artışlarının uzun dönemde büyümeyi sınırlı ölçüde arttırmasına sebebiyet verebilir.

\section{SONUÇ VE DEĞERLENDİRME}

Bir ekonomide meydana gelen yapısal değişim ve dönüşüm sürecini ifade eden kalkınma kavramı, özellikle günümüzde az gelişmiş ve GOÜ'ler açısından hayati öneme sahip olduğu aşikârdır. II. Dünya Savaşı sonrası dönemde geri kalmışlık sorununa yönelik önemli teorik çalışmalar yapıldığı ve gelişmiş ülkelerin refah seviyelerine erişmede GOÜ'lerin ve az gelişmiş ülkelerin hangi politikaları uygulayarak ve hangi finansman araçlarıyla bu gelişmişlik farkını kapatacağına yönelik incelemeler gerek akademik gerekse politik çevrelerde üzerinde durulan önemli hususların başında gelmiştir. Bir ülkenin kalkınmasında üretim artışlarının yani büyümenin de önemli belirleyici etmenlerden biri olduğu genel kabul gören bir düşüncedir. Dolayısıyla ekonomik büyümenin istikrarlı ve sürdürülebilir olması, GOÜ’ler açısından gelişmiş ülkelerle olan gelişmişlik farkının kapatılmasında hayati öneme sahiptir. $\mathrm{Bu}$ çerçevede sanayileşmenin ekonomik büyümenin itici gücü olduğunu sistematik olarak ilk kez ileri süren Kaldor (1966), sanayileşmeyle ekonomik büyüme arasındaki ilişkiyi üç farklı biçimde ele almış ve bu minvalde literatürde sanayileşmeyle ekonomik büyüme arasındaki ilişkiyi inceleyen pek çok uygulamalı çalışmanın da öncüsü olmuştur.

Bu çalışmada Kaldor'un (1966) ortaya koymuş olduğu perspektiften yola çıkarak, sanayileşme ile verimliliğin üretim üzerindeki etkisi, literatürdeki uygulamalı çalışmalardan farklı olarak hizmetler sektörünü de dikkate alacak şekilde analiz edilmiştir. Bu çerçevede Doğu Bloğunda yer alan ve büyük 
çoğunluğu dağılan SSCB ülkelerinden oluşan on üç geçiş ekonomisi için 1990-2018 dönemini kapsayacak şekilde dinamik panel veri analizi yardımıyla sanayileşme ve verimlilik artışlarının üretim üzerindeki etkisi incelenmiştir. $\mathrm{Bu}$ çerçevede panel eşbütünleşme testleri ve panel eşbütünleşme tahmincileriyle analizler gerçekleştirilmiştir. Buna göre, kurulan farklı modeller doğrultusunda kişi başı GSYİH, sanayi ve hizmetler sektörü katma değerleri ile sanayi ve hizmetler sektörü istihdam oranlarının uzun dönemde eşbütünleşik oldukları tespit edilmiştir. Eşbütünleşme ilişkisinin varlığının tespitinden sonra, değişkenler arasında uzun dönemli ilişkinin yönü ve büyüklüğünün tespiti için panel eşbütünleşme tahmincileriyle tahminler gerçekleştirilmiş ve birtakım önemli bulgulara ulaşılmıştır. Buna göre, Kaldor'un (1966) üç yasasının hizmetler sektörünü de dâhil edecek genişletildiği bu tahminlere göre söz konusu geçiş ekonomileri için Kaldor'un (1966) üç yasasının kısmen desteklenmesi söz konusu olmuştur. Sanayi sektöründeki katma değer artışlarının, "sanayinin büyümenin motoru" olduğu şeklindeki görüşü destekler nitelikte bulguyu ortaya koyması, ölçek ekonomilerinin boyutunun diğer sektörlere kıyasla fazla olması, sermayenin getirisinin fazla olması ve teknolojik açıdan da ileri ve geriye dönük bağlantıların daha fazla olması gibi gerekçelerle açıklanabilir. Bununla birlikte, Kaldor'un (1966) ikinci yasası olarak da bilinen Verdoorn yasası çerçevesinde, sanayi sektöründe ölçeğe göre artan getirilerin varlığı ve göreceli olarak daha nitelikli üretim faktörlerinin istihdamı ve daha ileri teknolojinin varlığı, verimliliği daha fazla arttırıcı etkiye sahip olduğunu göstermektedir. Öte yandan Kaldor'un (1966) üçüncü yasasının ise hizmetler ve diğer sektörlerde azalan verimler kanunun kısmen devreye girmesinden dolayı, incelenen ülkeler için kısmen geçerli olduğu sonucuna varılmıştır.

Elde edilen bulgular doğrultusunda, sanayi kesiminin hem verimlilik hem de üretimi arttırıc1 etkilerinin varlığı, incelenen ülkeler açısından kaynakların sanayi kesimine aktarılmasının önemini vurgulamaktadır. Sanayi kesimi gerek kendi bünyesinde geri ve ileri bağlantılar yaratma gerekse ölçek ekonomilerini uyarma yoluyla diğer kesimlerdeki teknolojik gelişimi ve verimliliği uyarıcı etkiler yaratabilir ve bu da hem büyüme hem de istihdamı arttırma gibi ülkelerin çözmek zorunda olduğu sorunları da uzun dönemde ortadan kaldırabilir. Ayrıca, bu ülkelerin ekonomik gelişimleri için sermaye birikimi de önemli bir etkendir. İç tasarruf kaynaklarının yetersiz olduğu düşünüldüğünde dış finansman kaynakları da sermaye birikimi için önemli hale gelmekte ve bu doğrultuda doğrudan yabancı yatırımların sanayi kesimine yönlendirilmesi teşvik edilerek, teknolojik gelişim ve faktör verimliliğinde artış sağlanarak, hızlı ve istikrarlı bir büyümenin önü açılabilir. 


\section{KAYNAKÇA}

Akbaş, Y.E., Şentürk, M., \& Sancar, C. (2013). Testing for Causality between the Foreign Direct Investment, Current Account Deficit, GDP and Total Credit: Evidence from G7. Panoeconomicus, 6: 791-812.

Alhowaish, A. K. (2014). Does the Service Sector Cause Economic Growth? Empirical Evidence from Saudi Arabia. Global Studies Journal, 7(2): 1-6.

Arısoy, İ. (2008). Türkiye’de Sanayi Sektörü-İktisadi Büyüme İlişkisinin Kaldor Hipotezi Çerçevesinde Test Edilmesi. Türkiye Ekonomik Kurumu, 1(1): 1-31.

Arısoy, İ. (2013). Kaldor Yasası Çerçevesinde Türkiye'de Sanayi Sektörü ve İktisadi Büyüme İlişkisinin Sınanması. Eskişehir Osmangazi Üniversitesi İktisadi ve İdari Bilimler Dergisi, 8(1): 143-162.

Atesoğlu, H. S. (1993). Manufacturing and Economic Growth in the United States. Applied Economics, 25(1): 67-69.

Attiah, E. (2019). The Role of Manufactoring and Service Sectors in Economic Growth: An Empirical Study of Developing Countries. European Research Studies Journal, 22(1): 112-127.

Bairam, E. (1991). Economic Growth and Kaldor's Law: the Case of Turkey, 1925-78. Applied Economics, 23(8): 1277-1280.

Breusch, T.S., \& Pagan, A.R. (1980). The Lagrange Multiplier Test and Its Application to Model Specification in Econometrics. Review of Economic Studies, 47: 239-253.

Çetin, M. (2009). Kaldor Büyüme Yasasının Ampirik Analizi: Türkiye ve AB Ülkeleri Örneği(19812007). Afyon Kocatepe Üniversitesi İktisadi ve İdari Bilimler Fakültesi Dergisi, 11(1): 355-373.

Diaz, B. A. (2003). Mexico's Industrial Engine of Growth: Cointegration and Causality. Revista Momento Economico, 126: 34-41.

Eberhard, M., \& Bond, S. (2009). Cross-Section Dependence in Nonstationary Panels: A Novel Estimator. MPRA Paper, 17870: 1-26.

Ener, M., \& Arıca, F. (2011). Is The Kaldor's Growth Law Valid For High Income Economies: A Panel Study. Research Journal of Economics, Business and ICT, 1: 60-64.

Erataş, F., Nur, B.H. ve Özçalık, M. (2013). Feldstein-Horioka Bilmecesinin Gelişmiş Ülke Ekonomileri Açısından Değerlendirilmesi: Panel Veri Analizi. Çankırı Karatekin Üniversitesi İktisadi ve İdari Bilimler Fakültesi Dergisi, 3(2): 18-33.

Fagerberg, J., \& Verspagen, B. (1999). Modern Capitalism in the 1970s and 1980s, In: M. Setterfield (Ed.), Growth, Employment and Inflation. Palgrave MacMillan: United Kingdom

Güçlü, M. (2013). Manufacturing and Regional Economic Growth in Turkey: A Spatial Econometric View of Kaldor's Laws. European Planning Studies, 21(6): 854-866.

Hadri, K. (2000). Testing for Stationarity in Heterogenous Panel Data. The Econometrics Journal, 3(2): 148-161.

Hansen , J., \& Zhang, J. (1996). A Kaldorian Approach to Regional Economic Growth in China. Applied Economics, 28(6): 679-685.

İnamoğlu, Y. (2013). Türkiye'de Hizmet Sektörünün Gelişimi ve Ekonomik Büyümeye Etkisi. Bülent Ecevit Ünveristesi Sosyal Bilimler Enstitüsü Iktisat Anabilim Dal, Yüksek Lisans Tezi.

Kaldor, N. (1966). Causes of the Slow Rate of Growth of the United Kingdom: An Inaugural Lecture. Cambridge University Press: Cambridge

Kaynak, M. (2011). Kalkınma iktisadı. (4.Baskı). Gazi Kitabevi: Ankara

Mamgain, V. (1999). Are the Kaldor-Verdoorn Laws Applicable in the Newly Industrializing Countries? Review of Development Economics, 3(3): 295-309. 
Marconi, N., de Borja Reis, C., \& de Araújo, E. (2016). Manufacturing and Economic Development: The Actuality of Kaldor's First and Second Laws. Structural Change and Economic Dynamics, 37: 75-89.

McCoskey, S., \& Kao, C. (1998). A Residual-Based Test of the Null of Cointegration in Panel Data. Econometric Reviews, 17: 57-84.

Mercan, M., Kizilkaya, O., \& Okde, B. (2015). Are The Kaldor's Laws Valid? Panel Data Analysis under Cross Section Dependency for NIC Countries. Procedia Economics and Finance, 23: 140145 .

Pesaran, M. H. (2004). General Diagnostic Tests for Cross-Section Dependence in Panels. IZA Discussion Paper, 1240: 1-39.

Pesaran, M. H. (2006). Estimation and Inference in Large Heterogeneous Panels with a Multifactor Error Structure. Econometrica, 74(4): 967-1012.

Pesaran, M. H. (2007). A Simple Panel Unit Root Test in the Presence of Cross-Section Dependence. Journal of Applied Econometrics, 22(2): 265-312.

Pesaran, M. H., \& Yamagata, T. (2008). Testing Slope Heterogeneity in Large Panels. Journal of Econometrics, 142(1): 50-93.

Rahman, M., Rahman, M., \& Hai-bing, W. (2011). Time Series Analysis of Causal Relationship among GDP, Agricultural, Industrial and Service Sector Growth in Bangladesh. China-USA Business Review, 10(1): 9-15.

Romero, J., \& McCombie, J. (2016). Differences in Increasing Returns between Technological Sectors: A Panel Data Investigation Using the EU KLEMS Database. Journal of Economic Studies, 43(5): 863-878.

Shuling, W., \& Donghui, L. (2010). An Empirical Analysis on the Relationship between Service Industry and Economic Growth. Proceedings of 2010 International Conference on Industry Engineering and Management, 44-48.

Stoneman, P. (1979). Kaldor's Law and British Economic Growth: 1800-1970. Applied Economics, 11(3): 303-319.

Swamy, P. A. V. B. (1970). Efficient Inference in Random Coefficient Regression Model. Econometrica, 38: 311-323.

Szirmai, A. (2009). Industrialisation as an Engine of Growth in Developing Countries. UNU-MERIT Working Paper Series, 2009-010, 1-48.

Szirmai, A. (2012). Industrialisation as an Engine of Growth in Developing Countries, 1950-2005. Structural Change and Economic Dynamics, 23: 406-420.

Tandrayen-Ragoobur, V. (2010). The Services Sector and Economic Growth in Mauritius. A Bounds Testing Approach to Cointergration. University of Mauritius Research Journal, 16: 313-331.

Tatoğlu, F.Y. (2012). Illeri Panel Veri Analizi: Stata Uygulamall. Beta Yayınları: İstanbul

Terzi, H., \& Oltulular, S. (2004). Türkiye'deki Sanayileşme ve Ekonomik Büyüme Arasındaki Nedensel İlişki. Doğuş Üniversitesi Dergisi, 5(2). 219-226.

Uğurlu, A., \& Tuncer, İ. (2017). Türkiye'de Sanayi ve Hizmet Sektörlerinin Büyüme ve İstihdama Katkıları: Girdi-Çıktı Analizi. Dokuz Eylül Üniversitesi İktisadi ve İdari Bilimler Fakültesi Dergisi, 32(1): 131-165.

Westerlund, J. (2007). Testing for Error Correction in Panel Data. Oxford Bulletin of Economics and Statistics, 69(6): 709-748.

Westerlund, J., \& Edgerton, L. D. (2007). A Panel Bootstrap Cointegration Test. Economic Letters, 97: 185-190. 
Yamak, N. (2000). Cointegration, Causality and Kaldor's Hypothesis: Evidence from Turkey, 19461995. Gazi Üniversitesi İ̈BF Dergisi, 2(1): 75-80.

Yetiz, F., \& Özden, C. (2017). Analysis of Causal Relationship Among GDP, Agricultural, İndustrial and Services Sector Growth in Turkey. Ömer Halisdemir Üniversitesi İktisadi ve İdari Bilimler Fakültesi Dergisi, 10(3): 75-84. 


\section{EXTENDED ABSTRACT}

The role of industrialization in ensuring the economic development is one of the most discussed topics in the literature especially in the Post II. World War. In this direction, industrialization has a key role in ensuring economic development for the less-developed and developing countries in where capital is scarce. Furthermore deficiency in capital accumulation is another major fact for these countries. On the other hand, rapid and sustainable growth is closely related with the expansion of the industrial sector. Based on Kaldor's (1966) view that industrialization is the locomotive of economic growth, this study aims to examine the effect of industrialization and productivity on production, by including the services sector, for 13 selected transition economies. For this purpose, the study also seeks answers to the following questions:

- What is the impact of industrial Sector value added on economic growth?

- What is the effect of services sector value added on economic growth?

- What is the impact of industrial sector value added on industrial sector employment?

- How does the value added of the services sector affect the employment of the services sector?

In line with the above stated objectives and research questions, the analysis was carried out by means of panel cointegration tests and cointegration estimators by incorporating the annual panel data set over the period of 1980-2018 for 13 selected transition economies of which disintegrated from the Eastern Bloc and the Union of Soviet Socialist Republics (USSR). Apart from the empirical studies in the literatüre, three different models developed by Kaldor (1966) have been augmented by including the services sector, different from the applied studies in the literature. Based on the view by Kaldor (1966) that industrialization is the "engine of growth", the effect of value added in industrial and services sectors on the gross domestic product (GDP) has been discussed. In the framework of the second model which is also known as Verdoorn Law, the impact of the industrial sector on productivity has been augmented by including the services sector. Finally, the effect of productivity in both sectors on production has been discussed within the framework of Kaldor's third model. The data related to the variables in the models were obtained from the World Development Indicators (WDI) database of the World Bank as the second data source.

The existence of long-term relationships between variables within the framework of different models was examined by means of panel cointegration tests. The proper performance of panel cointegration tests also depends on the structure of the panel data examined. Therefore, homogeneity tests developed by Pesaran and Yamagata (2008) were applied to see the properties of the panel data set more concretely, and the null hypothesis emphasizing the presence of homogeneity was rejected for each model. In addition, cross section dependency tests developed by Pesaran (2004) were also employed to test the existence of the relationship between cross section units. As a result of the CD and CDLM tests, the null hypothesis, which emphasizes the cross-sectional independence, was rejected at $1 \%$ significance level for each model. Detecting the existence of a long-term relationship between series under the heterogeneous structure of the panel data set and the presence of cross-sectional dependency is handled in a different way. Before proceeding to the panel cointegration analysis, which will be used in determining the existence of a long-term relationship between series, it should be carefully examined whether the series contain unit root or not. Especially in the analyses conducted by time series, spurious regression problem may arise in the estimations to be made in the presence of unit root. This situation is a major problem that is encountered in panel data analysis as well. Accordingly, whether the series have a unit root or not was examined by performing Hadri (2000) LM stationary test and the CADF test developed by Pesaran (2007). According to the results of both tests, it was observed that the series become stationary by first differencing. This indicates that the series may be cointegrated in the long run, and panel cointegration tests have been employed in this framework. Within the framework of different models suggested by Kaldor (1966), the existence of long-term relationship was tested with the help of ECM test based on error correction mechanism by Westerlund (2007) and LM test developed by Westerlund and Edgerton (2007). According to the results, the variables are cointegrated in the long run.

After determining the existence of the cointegration relationship, panel cointegration estimators were performed for the direction and size of the long term relationship. In this context, estimations were conducted by the common correlated effects estimator (CCE) developed by Pesaran (2006) and the advanced mean group estimator (AMG) methods developed by Eberhard and Bond (2009). According to the estimation results, it is concluded that the value added in the industrial sector has a greater effect on increasing the production compared to the services sector. In addition, the productivity in the industrial sector increases the production more than the productivity in the services and other sectors stands out as another major finding of the paper. According to these estimates that Kaldor's (1966) three laws were augmented by including the services sector, the three laws of Kaldor (1966) were partially supported for these transition economies. The fact that the findings support the view that the 
industry is the engine of economic growth can be explained by some possible reasons. First, economies of scale are larger in size compared to other sectors. Second, the return on capital is greater in the manufacturing industry sector. Third, technologically forward and backward linkages are more pronounced in the manufacturing industry compared to other sectors. However, within the framework of Verdoorn's law, also known as the second law of Kaldor (1966), the existence of increasing returns to scale in the industrial sector and the employment of relatively more qualified production factors and the presence of more advanced technology show that it has a more increasing effect on productivity. On the other hand the third law of Kaldor (1966) is partially valid for the countries examined, due to the partial presence of the law on diminishing returns in services and other sectors.

In line with the findings, the existence of both productivity and production-enhancing effects of the industrial sector emphasizes the importance of transferring resources to the industrial sector for these countries in the sample. The industrial sector might stimulate technological development and productivity in other segments either by creating backward and forward linkages or stimulating economies of scale, and this situation might eliminate the problems that countries have to solve in the long run, such as both growth and increasing employment. In addition, capital accumulation is an important factor for the economic development of these countries. Considering that domestic savings resources are insufficient, external financing resources also become important for capital accumulation, and in this direction, foreign direct investments could be encouraged to the industrial sector. Hence, this situation can contribute to rapid and sustainable growth by leading to technological progress and increases in factor productivity. 